\title{
Palladium(II) Complexes with Phosphorus-Nitrogen Mixed Donors. Efficient Catalysts for the Heck Reaction
}

\author{
K. Rajender Reddy, K. Surekha, Gene-Hsiang Lee, Shie-Ming Peng, and \\ Shiuh-Tzung Liu* \\ Department of Chemistry, National Taiwan University, Taipe, Taiwan 106, Republic of China
}

Received February 2, 2000

Summary: $\mathrm{Pd}(\mathrm{II})$ complexes of phosphine-nitrogen $(\mathrm{P}-$ N) bi dentate donors act as efficient catalysts for theHeck reaction. In a typical example, reaction of phenyl iodide with methyl acrylate in N-methyl pyrrolidinone (NMP) at ca. $130^{\circ} \mathrm{C}$ provides the Heck product with a turnover number of up to $10^{6}$. In addition, the coupling reaction of 4-bromoacetophenone with olefin in a quantitative yield was achieved by using the same catalyst in the presence of sodium iodide.

\section{Introduction}

Olefination of aryl halides, known as the Heck reaction, is an important transition-metal-catalyzed reaction for organic synthesis. ${ }^{1}$ The discovery of efficient palladium complexes for this reaction has been received much attention due to their industrial applications. It is reported that $\mathrm{Pd}(\mathrm{II})$ complexes of common $\mathrm{P}-\mathrm{P}$ or $\mathrm{N}-\mathrm{N}$ bidentate ligands are generally less active. ${ }^{2} \mathrm{How}-$ ever, Shaw and co-workers recently demonstrated that palladium complexes of chelating diphosphines are excellent catalysts. ${ }^{3}$ Other ligand combinations of palladium(II) providing good catalytic activity are cyclometalated phosphines ${ }^{4}$ and imines, ${ }^{5}$ carbene, ${ }^{6}$ and dimethylglycine, ${ }^{7}$ but mixed phosphorus-nitrogen donors as ligands in the Heck reaction have rarely been reported. We are currently involved in developing palladium-based catalysts with bidentate phosphine-imine $(\mathrm{P}-\mathrm{N})$ ligands, in which imine acts as a weak $\pi$-acceptor and phosphine as a good $\sigma$-donor, and demonstrated that palladium complexes with the mixed donor system $\mathbf{L}_{\mathbf{2}}$ show unusual influence in stabilizing the insertion product. ${ }^{8}$ Here we investigate the high catalytic activity

* To whom correspondence should be addressed. E-mail: stliu@ ccms.ntu.edu.tw

(1) (a) Heck, R. F. Palladium Reagents in Organic Synthesis; Academic Press: London, 1985. (b) de Meijere, A.; Meyer, F. E. Angew. Chem., Int. Ed. Engl. 1994, 33, 2379. (c) Carbri, W.; Candiani, I. Acc. Chem. Res. 1995, 28, 2.

(2) (a) Carbri, W.; Candiani, I.; Bedeschi, A.; Santi, R. J . Org. Chem. 1990, 55, 3654 (b) Carbri, W.; Candiani, I.; Bedeschi, A.; Santi, R. Synlett 1992, 871.

(3) Shaw, B. L.; Perera, S. D. Chem. Commun. 1998, 1863.

(4) (a) Shaw, B. L.; Perera, S. D.; Staley, E. A. Chem. Commun. 1998 1361. (b) Herrmann, W. A.; Brossmer, C.; Reisinger, C.-P.; Reiemeier T. H.; Öfele, K.; Beller, M. Chem. Eur. J . 1997, 3, 1357 (c) Ohff, M.; Ohff, A.; van der Boom, M. F.; Milstein, D. J . Am. Chem. Soc. 1997, 119, 11687.

(5) Ohff, M.; Ohff, A.; Milstein, D. Chem. Commun. 1999, 357

(6) Herrmann, W. A.; Elison, M.; Fisher, J .; Köcher, C.; Artus, G. R. A. Angew. Chem., Int. Ed. Engl. 1995, 34, 2371.

(7) Reetz, M. T.; Westermann, E.; Lohmer, R.; Lohmer, G. Tetrahedron Lett. 1998, 39, 8449.

(8) Reddy, K. R.; Chen, C.-L.; Liu, Y.-H.; Peng, S.-M.; Chen, J .-T.; Liu, S.-T. Organometallics 1999, 18, 2574. of the pal ladium complexes associated with the ligands $\mathbf{L}_{\mathbf{1}}-\mathbf{L}_{\mathbf{3}}$ in the Heck reaction.<smiles>Nc1ccccc1P</smiles>

$L_{1}$<smiles>Pc1ccccc1/C=N/c1ccccc1P</smiles>

$\mathrm{L}_{2}$<smiles>Pc1ccccc1/C=N/c1ccccc1P</smiles>

$L_{3}$

\section{Results and Discussion}

Palladium(II) Complexes. Palladium complexes $\left[\left(L_{n}\right) P d P h l\right](\mathbf{1}, n=1 ; 2, n=2 ; 3, n=3)$ are readily prepared by oxidative addition of phenyl iodide to a mixture of $\mathrm{Pd}(\mathrm{dba})_{2}$ and the corresponding ligand in THF solution. All these complexes are stable in air and<smiles>IP(c1ccccc1)[P-]1(I)Nc2ccccc2P1</smiles>

1<smiles>P=CN1c2ccccc2P(c2ccccc2)[P-]1(I)c1ccccc1</smiles>

2<smiles>I[P-]1(c2ccccc2)[P+](c2ccccc2)=Cc2ccccc2[PH]1(I)c1ccccc1</smiles>

3 can be handled in the atmosphere. Formation of only one isomer, in which the phenyl ligand is cis to the phosphine donor, is evident from the appearance of a single phosphorus signal in ${ }^{31} \mathrm{P}$ NMR spectra and the crystal structures of $\mathbf{2}$ and $\mathbf{3}$. This stereoarrangement is in general agreement with the reported $[\mathrm{Pd}(\mathrm{P}-\mathrm{N})$ RX] complexes. ${ }^{9}$

Heck Reaction. In a typical experiment for the reaction, aryl halides, olefins, and triethylamine in a 1:1.5:1 ratio were added to a freshly distilled $\mathrm{N}$ methylprrolidinone (NMP) solution, followed by the addition of the catalyst. The mixture was heated in an oil bath for the specified temperature and time. After the reaction was stopped, the reaction mixture was diluted with dichloromethane and washed with $5 \mathrm{~N} \mathrm{HCl}$ and water. The organic portion was separated, dried with $\mathrm{Na}_{2} \mathrm{SO}_{4}$, and concentrated. The desired product was either characterized by ${ }^{1} \mathrm{H}$ NMR spectroscopy directly or separated by column chromotography. All of the results are summarized in Table 1.

Complete conversions of phenyl iodide and methyl acrylate into methyl cinnamate were observed with catalysts 1 and 3 at various temperatures $\left(110-130^{\circ} \mathrm{C}\right)$,

(9) (a) Brinkmann, P. H. P.; Luinstra, G. A. J . Organomet. Chem 1999, 572, 193. (b) Dekker, G. P. C. M.; Buijs, A.; Elsevier, C. J .; Vrieze, K.; van Leeuwen, P. W. N. M.; Smeets, W. J . J .; Spek, A. L.; Wang, Y. F.; Stam, C. H. Organometallics 1992, 11, 1937. 
Table 1. Results of the Heck Reaction Catalyzed by [(P-N)PdPhI ]

\begin{tabular}{|c|c|c|c|c|c|c|}
\hline entry & $\operatorname{ArX}(\mathrm{amt}, \mathrm{mmol})$ & alkene (amt, mmol) & catalyst (amt, mmol) & $t(h)$ & temp, ${ }^{\circ} \mathrm{C}$ & yield (\%) (TON) \\
\hline 1 & Phl (10) & MA (15) & $\mathbf{1}\left(3.5 \times 10^{-5}\right)$ & 21 & 120 & $100(285700)^{a}$ \\
\hline 2 & Phl (50) & MA (75) & $\mathbf{1}\left(3.5 \times 10^{-5}\right)$ & 137 & 120 & $55(785700)^{a}$ \\
\hline 3 & Phl (10) & styrene (15) & $\mathbf{1}\left(3.5 \times 10^{-5}\right)$ & 22 & 120 & $36(102800)^{b}$ \\
\hline 4 & Phl (10) & $\mathrm{MA}(15)$ & $\mathbf{2}\left(3.5 \times 10^{-5}\right)$ & 22 & 120 & $53(151400)^{a}$ \\
\hline 5 & Phl (50) & styrene (75) & $2\left(3.5 \times 10^{-4}\right)$ & 48 & 130 & $80(114800)^{b}$ \\
\hline 6 & $\mathrm{Phl}$ (10) & MA (15) & $\mathbf{3}\left(3.5 \times 10^{-5}\right)$ & 22 & 130 & $100(285700)^{a}$ \\
\hline 7 & Phl (10) & MA (15) & $\mathbf{3}\left(3.5 \times 10^{-5}\right)$ & 22 & 110 & $100(285700)^{a}$ \\
\hline 8 & Phl (50) & MA (75) & $\mathbf{3}\left(3.5 \times 10^{-5}\right)$ & 168 & 130 & $80(1 \quad 142800)^{a}$ \\
\hline 9 & bap (10) & MA (15) & $2\left(3.5 \times 10^{-4}\right)$ & 94 & 140 & $43(12285)^{\mathrm{a}}$ \\
\hline $10^{9}$ & bap (10) & MA (15) & $\mathbf{2}\left(3.5 \times 10^{-4}\right)$ & 94 & 140 & $100(28570)^{a, c}$ \\
\hline 119 & bap (10) & styrene (15) & $\mathbf{2}\left(3.5 \times 10^{-4}\right)$ & 97 & 140 & $100(28570)^{a}$ \\
\hline $12^{\mathrm{g}}$ & bap (10) & MA (15) & $\mathbf{1}\left(3.5 \times 10^{-4}\right)$ & 70 & 130 & $100(28570)^{a, c}$ \\
\hline 139 & bap (10) & styrene (15) & $1\left(3.5 \times 10^{-4}\right)$ & 95 & 130 & $40(11428)^{a}$ \\
\hline 149 & bap (10) & MA (15) & $\mathbf{3}\left(3.5 \times 10^{-4}\right)$ & 70 & 120 & $50(14285)^{a, d}$ \\
\hline $15^{9}$ & bap (10) & MA (15) & $2\left(3.5 \times 10^{-5}\right)$ & 70 & 140 & $35(100000)^{a, e}$ \\
\hline 169 & bnb (10) & styrene (15) & $\mathbf{2}\left(3.5 \times 10^{-.3}\right)$ & 60 & 130 & $26(744)^{b}$ \\
\hline 179 & $\operatorname{PhBr}(10)$ & $\mathrm{MA}(15)$ & $\mathbf{2}\left(1.75 \times 10^{-3}\right)$ & 72 & 140 & $10(571)^{b, f}$ \\
\hline 18 & Phl (50) & $M A(75)$ & $\mathrm{Pd}(\mathrm{dba})_{2}+\mathbf{L}_{2}\left(3.5 \times 10^{-2}\right)$ & 21 & 130 & $57(814)^{\mathrm{b}}$ \\
\hline 19 & Phl (10) & styrene (15) & $P d(d b a)_{2}+\mathbf{L}_{2}\left(3.5 \times 10^{-2}\right)$ & 91 & 130 & $65(185)^{b}$ \\
\hline 20 & bab (10) & styrene (15) & $\mathrm{Pd}(\mathrm{dba})_{2}+\mathbf{L}_{\mathbf{1}}\left(1.0 \times 10^{-1}\right)$ & 147 & 130 & $43(43)^{\mathrm{b}}$ \\
\hline
\end{tabular}

a NMR yield. b I solated yield. c A mixture of methyl 3-(4-acetylphenyl)acrylate and sodium 3-(4-acetylphenyl)acrylate (25:75). d Only methyl 3-(4-acetyl phenyl)acrylate. ${ }^{e}$ A mixture of methyl 3-(4-acetyl phenyl)acrylate and sodium 3-(4-acetyl phenyl)acrylate (20:80). ${ }^{f}$ Pure sodium 3-(4-acetylphenyl)acrylate. ${ }^{\mathrm{g}} \mathrm{Nal}$ promotor added.

respectively (entries 1,6 , and 7). On the other hand, compound $\mathbf{2}$ shows a lower conversion with respect to 1 and $\mathbf{3}$ (compare entry 4 with entries 1 and 7). The lower activity of $\mathbf{2}$ is thought to be due to its steric arrangement, determined by crystal structure analysis (crystallography). Catalysts $\mathbf{1}$ and $\mathbf{3}$ appear to be active even for a longer period of time at high temperature (entries 2 and 8). No deposition of palladium black during these reactions was observed, indicating the stability of these complexes. In fact, the catalyst remains active upon the addition of more substrates when the reaction is complete. High yields and high turnover number (TON up to $10^{6}$, entry 8) shows the efficiency of these catalysts, which is comparable with the most active catalysts reported so far. ${ }^{3-7}$

As for the aryl bromide, a lower conversion rate was observed for the reaction of 4-bromoacetophenone (bap) with methyl acrylate. For example, a reaction carried out at $140{ }^{\circ} \mathrm{C}$ for $94 \mathrm{~h}$ only provides $43 \%$ of the Heck product (entry 9). However, the addition of sodium iodide to the reaction mixture readily improves the yield and a complete conversion was obtained (entry 10). However, under such reaction conditions, the hydrolysis product sodium 3-(4-acetyl phenyl)acrylate becomes the major product. Addition of $\mathrm{Nal}$ is also effective in the coupling of 4-bromoacetophenone with styrene to yield 4-acetylstilbene (entry 13). A maximum TON of $10^{5}$ was achieved with bap and methyl acrylate at lower concentrations of catalyst (entry 15). With regard to the higher conversions in the presence of added $\mathrm{Nal}$ salt, it is already known that addition of salts such as alkalimetal halides, $\mathrm{Bu}_{4} \mathrm{NX}(\mathrm{X}=\mathrm{Cl}, \mathrm{Br})$, facilitates the Heck reaction by promoting the oxidative addition step. ${ }^{10,11}$ However, such a promoter was not necessary for aryl iodides, which undergo a faster oxidative addition with $\mathrm{Pd}(0)$ species. Simple bromobenzene is also found to undergo a coupling reaction with methyl acrylate, but at a very slow conversion rate (entry 17). When the study is extended further, reaction of p-bromonitrobenzene (bnb) with styrene gave $\mathrm{p}$-nitrostil bene in $26 \%$ yield

(10) Shaw, B. L. New J . Chem. 1998, 77.

(11) Merlic, C. A.; Semmelhack, H. F. J . Organomet. Chem. 1990 391, C23.
(E entry 16). However, no coupling product was observed with p-bromoanisole or 2-chloropyridine and methyl acrylate.

For comparison, the catalytic system generated by the conventional manner was studied (entries 18-20). A mixture of $\mathrm{Pd}(\mathrm{dba})_{2}$ and ligand acting as the catalyst in the reaction provides the low conversion of phenyl iodi de into trans-cinnamate and trans-stilbene. In fact, a small amount of palladium black precipitated during the reaction. This outcome clearly suggests that the catalytic behavior of complexes $\mathbf{1 - 3}$ is different from that of the in situ generated species.

Crystallography. Single crystals suitable for X-ray analysis of complexes $\mathbf{2}$ and $\mathbf{3}$ are obtained by slow evaporation of dichloromethane/hexane solutions. The crystal data are given in Table 2. ORTEP drawings of these complexes are depicted in Figures 1 and 2, respectively, and selected bond distances and bond angles are summarized in Table 3.

Both palladium(II) complexes are square planar. Phenyl and phosphine ligands are cis to each other in both 2 and 3. $\mathrm{Pd}-\mathrm{C}$ distances are in the range 2.008$2.03 \AA$ and are typical palladium-aryl carbon lengths. ${ }^{12}$ All other bond distances and bond angles lie within the normal range, except the larger deviation of $\mathrm{P}-\mathrm{Pd}-\mathrm{I}$ $\left(166.56(7)^{\circ}\right)$ for $\mathbf{2}$. This angular deviation is attributed to the steric effect of the phenyl group of the imine moiety, which lies perpendicular to the plane. Such steric hindrance might also be responsible for the lower reactivity of the palladium complex $\mathbf{2}$ on the oxidative addition of aryl halides. At the same time, from entries 1 and 6 (Table 1), it is clear that the ring size of the complexes does not have an influence on the efficiency of the catalysts.

In conclusion, the $[\mathrm{Pd}(\mathrm{P}-\mathrm{N}) \mathrm{Phl}]$ complexes reported here show a very high activity for aryl iodides and activated bromides for the Heck reaction. Further investigation in understanding the scope of these ligand systems for commercially cheaper aryl chlorides is presently underway.

(12) Crociani, L.; Bandoli, G.; Domella, A.; Basato, M.; Corain, B. Eur. J . Inorg. Chem. 1998, 1811. 


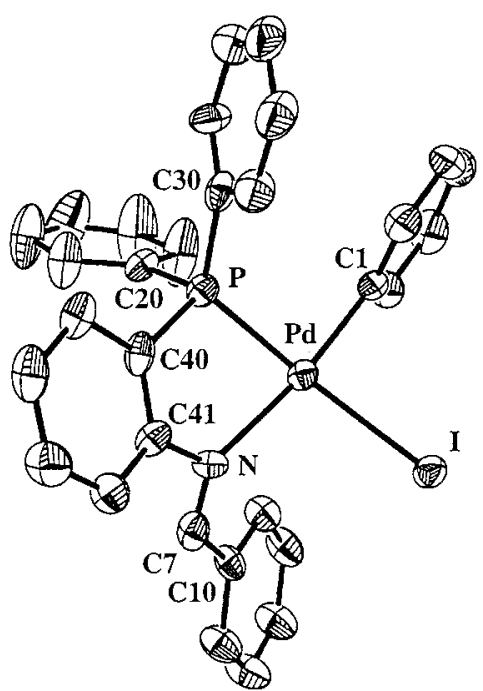

Figure 1. ORTEP plot of $\mathbf{2}$.

Table 2. Crystal Data of 2 and 3

\begin{tabular}{|c|c|c|}
\hline & 2 & 3 \\
\hline $\begin{array}{l}\text { formula } \\
\text { fw }\end{array}$ & $\begin{array}{l}\mathrm{C}_{31} \mathrm{H}_{25} \mathrm{INPPd} \\
675.79\end{array}$ & $\begin{array}{l}\mathrm{C}_{31} \mathrm{H}_{25} \mathrm{INPPd} \\
675.49\end{array}$ \\
\hline cryst syst & monoclinic & triclinic \\
\hline space group & $P 2_{\sqrt{ }} / \mathrm{C}$ & $\mathrm{P} \overline{1}$ \\
\hline a, $\AA$ & 12. & $9.339(2)$ \\
\hline b, $\AA$ & 10. & $44(2)$ \\
\hline$c, \AA$ & $23.8338(5)$ & $13.179(3)$ \\
\hline$\alpha$, deg & 90 & $87.49(3)$ \\
\hline$\beta$, deg & $100.256(1)$ & $85.50(3)$ \\
\hline$\gamma$, deg & 90 & $82.98(3)$ \\
\hline & & \\
\hline $\mathrm{V}, \AA^{3}$ & 3181.8(1) & $1344.1(5)$ \\
\hline $\mathrm{D}_{\text {calcd }}, \mathrm{g} \mathrm{cm}^{-3}$ & 1.411 & 1.670 \\
\hline $\begin{array}{l}\mu, \mathrm{mm}^{-1} \\
\text { radiation }\end{array}$ & $\begin{array}{l}1.621 \\
\operatorname{MoK} \alpha(0.7107 \AA)\end{array}$ & $\begin{array}{l}1.670 \\
\operatorname{MoK} \alpha(0.7107 \AA)\end{array}$ \\
\hline temp, $\mathrm{K}$ & $295(2)$ & $293(2)$ \\
\hline $\begin{array}{l}F(000) \\
\text { cryst size, mm }\end{array}$ & $\begin{array}{l}1328 \\
0.56 \times 0.10 \times 0.02\end{array}$ & $\begin{array}{l}664 \\
0.25 \times 0.30 \times 0.35\end{array}$ \\
\hline$\theta$ range, & $1.59-26.39$ & $1.55-24.97$ \\
\hline indexli & $\begin{array}{l}-15 \leq h \leq 16 \\
-13 \leq k \leq 13 \\
-29 \leq 1 \leq 26\end{array}$ & $\begin{array}{l}-10 \leq h \leq 11 \\
0 \leq k \leq 13 \\
-15 \leq \mathrm{I} \leq 15\end{array}$ \\
\hline ר. of rflns collected & 14881 & 4710 \\
\hline no. of inde & $6423\left(R_{\text {int }}=0.0810\right)$ & $4710\left(R_{\text {int }}=0.00\right)$ \\
\hline abs cor & empirical & $\begin{array}{l}\text { semiempirical } \\
\text { from } \psi \text { scan }\end{array}$ \\
\hline max, min transmissn & $0.8015,0.4840$ & $0.656,0.497$ \\
\hline efinem & & es on $\mathrm{F}^{2}$ \\
\hline $\begin{array}{l}\text { goodnes } \\
\text { final } \mathrm{R}\end{array}$ & 1.049 & 1.068 \\
\hline final $\mathrm{r}$ & $\begin{array}{l}R 1=0.0700 \\
\quad w R 2=0.1687\end{array}$ & $\begin{array}{l}R 1=0.0336 \\
w R 2=0.0900\end{array}$ \\
\hline $\begin{array}{l}\text { largest diff peak } \\
\text { and hole, } e \AA^{-3}\end{array}$ & $1.461,0.744$ & $1.369,-0.925$ \\
\hline
\end{tabular}

\section{Experimental Section}

General Information. All reactions, manipulations, and purifications steps were performed under a dry nitrogen atmosphere. Tetrahydrofuran was distilled under nitrogen from sodium benzophenone ketyl. Dichloromethane and acetonitrile were dried with $\mathrm{CaH}_{2}$ and distilled under nitrogen. Other chemicals and solvents were of analytical grade and were used as received unless otherwise stated.

NMR spectra were recorded on Bruker AC-E 200 or AM300 spectrometers. Elemental analyses were determined with a Perkin-Elmer 240C instrument.

General Procedure for Preparation of 1-3. To a mixture of $\mathrm{Pd}(\mathrm{dba})_{2}(575 \mathrm{mg}, 1 \mathrm{mmol}$ ) and the corresponding ligand ( $1 \mathrm{mmol}$ ) in $15 \mathrm{~mL}$ of THF was added $0.5 \mathrm{~mL}(4 \mathrm{mmol})$ of phenyl iodide, and the mixture was stirred at room temperature for $1 \mathrm{~h}$. The resulting precipitate was filtered, washed with a small amount of ether, and dried under vacuum.

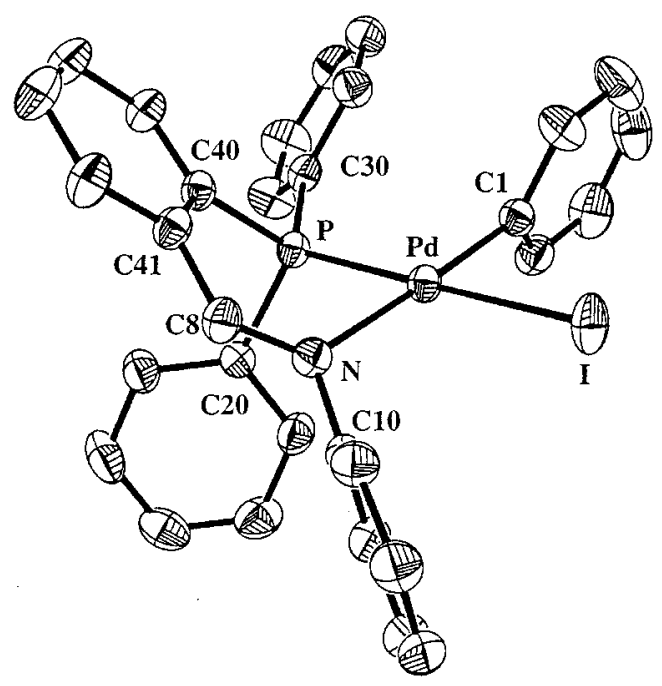

Figure 2. Molecular structure of $\mathbf{3}$ (thermal ellipsoids drawn at the $30 \%$ probability level).

Table 3. Selected Bond Distances $(\AA \AA)$ and Bond Angles (deg)

\begin{tabular}{lll}
\hline & \multicolumn{1}{c}{$\mathbf{2}$} & \multicolumn{1}{c}{$\mathbf{3}$} \\
\hline $\mathrm{Pd}-\mathrm{C} 1$ & $2.03(1)$ & $2.008(4)$ \\
$\mathrm{Pd}-\mathrm{P}$ & $2.235(3)$ & $2.236(1)$ \\
$\mathrm{Pd}-\mathrm{N}$ & $2.188(8)$ & $2.182(3)$ \\
$\mathrm{Pd}-1$ & $2.6697(9)$ & $2.6374(9)$ \\
$\mathrm{C} 7-\mathrm{N}$ & $1.25(1)$ & $1.277(5)$ \\
$\mathrm{N}-\mathrm{C} 8$ & & $84.47(9)$ \\
$\mathrm{P}-\mathrm{Pd}-\mathrm{N}$ & $80.3(2)$ & $93.6(1)$ \\
$\mathrm{P}-\mathrm{Pd}-\mathrm{C} 1$ & $92.7(3)$ & \\
$\mathrm{P}-\mathrm{Pd}-\mathrm{I}$ & $166.56(7)$ & $177.39(3)$ \\
$\mathrm{C}-\mathrm{N}-\mathrm{Pd}$ & $132.3(7)$ & \\
$\mathrm{C} 7-\mathrm{N}-\mathrm{C} 41$ & $114.3(8)$ & \\
$\mathrm{N}-\mathrm{C} 8-\mathrm{C} 41$ & & $127.0(4)$ \\
$\mathrm{C}-\mathrm{N}-\mathrm{Pd}$ & & $126.6(3)$ \\
$\mathrm{C}-\mathrm{Pd}$
\end{tabular}

Complex 1: yield $460 \mathrm{mg}(70 \%) ;{ }^{1} \mathrm{H} \mathrm{NMR} \delta\left(\mathrm{CD}_{2} \mathrm{Cl}_{2}\right) 4.76$ (s, 2H, $\left.\mathrm{NH}_{2}\right), 6.72-7.53\left(\mathrm{~m}, 19 \mathrm{H}\right.$, aromatic); ${ }^{31} \mathrm{P} \mathrm{NMR} \delta 34.3$. Anal. Calcd for $\mathrm{C}_{24} \mathrm{H}_{21} \mathrm{NPIPd} \cdot \mathrm{THF}$ : C, 51.28; $\mathrm{H}, 3.84 ; \mathrm{N}, 2.13$. Found: C, 50.96; H, 3.57; N, 1.98.

Complex 2: yield $525 \mathrm{mg}(78 \%) ;{ }^{1} \mathrm{H} \mathrm{NMR} \delta\left(\mathrm{CDCl}_{3}\right) 6.52-$ $7.58(\mathrm{~m}, 22 \mathrm{H}$, aromatic), $8.64(\mathrm{~m}, 3 \mathrm{H}$, imine proton + two aromatic protons); ${ }^{31} \mathrm{P}$ NMR $\delta 22.83$. Anal. Calcd for $\mathrm{C}_{31} \mathrm{H}_{25^{-}}$ NPIPd: Calcd: C, 55.10; H, 3.72; N, 2.10. Found: C, 54.74; $\mathrm{H}, 3.52, \mathrm{~N}, 2.12$

Complex 3: yield $545 \mathrm{mg}(80 \%)$; ${ }^{1 \mathrm{H}} \mathrm{NMR} \delta\left(\mathrm{CDCl}_{3}\right) 6.44-$ 7.65 (m, 24H, aromatic), 8.14 (s, 1H, imine); ${ }^{31} \mathrm{P}$ NMR $\delta 23.15$. Anal. Calcd for $\mathrm{C}_{31} \mathrm{H}_{25} \mathrm{NPIPd}$ C, 55.10; $\mathrm{H}, 3.72 ; \mathrm{N}, 2.10$. Found: C, 54.62; H, 3.76; N, 1.87.

Crystallography. Crystals of $\mathbf{2}$ and $\mathbf{3}$ were obtained by recrystallization from slow evaporization of a solution in dichloromethane/hexane. Cell parameters of $\mathbf{2}$ and $\mathbf{3}$ were determined on a Siemens SMART CCD instrument and refined by full-matrix least squares on $\mathrm{F}^{2}$. The crystal data are listed in Table 2, and selected bond distances and bond angles are collected in Table 3. Other crystallographic data are supplied as Supporting Information.

Acknowledgment. Financial support for this work from the National Science Council of Taiwan, ROC (Grant No. NSC88-2113-M002-32), is acknowledged.

Supporting Information Available: Complete description of the X-ray crystallographic structure determination of $\mathbf{2}$ and $\mathbf{3}$, including tables of atomic coordinates, isotropic and anisotropic thermal parameters, and bond distances and angles. This material is available free of charge via the Internet at http://pubs.acs.org.

$\mathrm{OM} 000089 \mathrm{H}$ 